\title{
THE SYNDROME OF PULMONARY STENOSIS COMPLICATING MATERNAL RUBELLA
}

\author{
BY \\ A. W. VENABLES \\ From the Royal Children's Hospital, Melbourne, Australia
}

Received April 30, 1964

The clinical features of pulmonary stenosis following maternal rubella during pregnancy differ regularly from those of simple pulmonary valve stenosis. In the rubella syndrome there is an association between pulmonary stenosis and patent ductus (Heiner and Nadas, 1958; Rowe, 1963), ejection sounds are not usually present, the systolic murmur often radiates widely even when not particularly loud at the pulmonary area, and post-stenotic dilatation of the main pulmonary artery is not seen. Rowe (1963) reported the findings in 11 such patients. The mothers of 7 of these patients developed rubella during an epidemic which occurred in New Zealand in 1959. Pulmonary artery stenosis was present in all, being bilateral in 9. Some degree of pulmonary valve stenosis was also present in all but one patient. This report describes similar observations made independently during 1963 at the Royal Children's Hospital, Melbourne, on a further 5 non-epidemic patients, and refers to 9 other patients with the syndrome who have not been investigated fully.

\section{SUBJECTS}

Four patients with the syndrome of pulmonary stenosis following maternal rubella have been investigated fully by cardiac catheterization and selective angiocardiography, while one such infant has undergone necropsy after dying from respiratory infection. In 9 other patients with similar clinical pictures the anatomy of the pulmonary stenosis has not been elucidated.

\section{FINDINGS}

Table I shows the over-all impact of maternal rubella in these patients, the five fully documented patients being listed as Cases 1 to 5 , inclusive.

The cardiac signs were similar both in those who were fully documented and in the other patients. The presence of a patent ductus modified or largely obscured the signs of pulmonary stenosis, but when pulmonary stenosis existed alone or a coexistent patent ductus had been closed, the auscultatory signs were as follows. There was always a systolic murmur, maximal at the pulmonary area, which ranged in intensity between moderately loud and loud. There was variable, but in some cases extensive, radiation of the systolic murmur through the chest, and early systolic ejection sounds were not usually present. The second heart sound appeared essentially normal. The effect of a coexistent patent ductus on these signs depended on the size of the ductus and the flow through it. With a big ductus there was merely unusual radiation through the chest of the systolic component of the murmur. With a small ductus a faint continuous murmur was added at the pulmonary area to the signs of the isolated lesion.

Radiography showed hearts of fairly normal size with no abnormal prominence of the main pulmonary artery and with normal pulmonary vasculature, except in infants with significant left-toright shunt, who exhibited cardiac enlargement and pulmonary plethora.

Electrocardiograms showed variable degrees of right ventricular loading, but this was never severe. 
TABLE I

General Features of Pulmonary Stenosis following Maternal Rubella

\begin{tabular}{|c|c|c|c|c|c|c|c|c|}
\hline $\begin{array}{l}\text { Case } \\
\text { No. }\end{array}$ & $\begin{array}{l}\text { Date of } \\
\text { birth }\end{array}$ & $\begin{array}{l}\text { Timing of } \\
\text { rubella in } \\
\text { gestational } \\
\text { period }\end{array}$ & $\begin{array}{l}\text { Birth } \\
\text { weight } \\
\text { (kg.) }\end{array}$ & $\begin{array}{c}\text { Ocular } \\
\text { abnormalities }\end{array}$ & Deafness & $\begin{array}{c}\text { Mental } \\
\text { retardation }\end{array}$ & $\begin{array}{l}\text { Patent } \\
\text { ductus }\end{array}$ & $\begin{array}{l}\text { Pulmonary } \\
\text { stenosis }\end{array}$ \\
\hline 1 & 28.4.57 & 1st month & 1.91 & Unilateral cataract & + & - & - & + \\
\hline $2^{*}$ & 24.3 .58 & No history & $1 \cdot 53$ & - & + & 一 & + & + \\
\hline 3 & 9.8 .61 & 1st month & $2 \cdot 22$ & Chorioretinopathy & - & + & + & + \\
\hline $4 \dagger$ & 20.6 .63 & 3rd week & $1 \cdot 62$ & - & $?$ & - & - & + \\
\hline 5 & 29.9 .63 & 1st week & $2 \cdot 16$ & 一 & - & - & + & + \\
\hline $6 \ddagger$ & 30.4 .52 & ? & $?$ & & + & - & + & Probable \\
\hline 7 & 11.2 .58 & No history & $2 \cdot 72$ & L. cataract & - & - & + & Probable \\
\hline 8 & 14.8 .58 & 7 weeks & $3 \cdot 36$ & - & - & - & - & Probable \\
\hline 9 & 4.10 .59 & 2 months & $2 \cdot 92$ & - & - & - & - & Probable \\
\hline 10 & 8.9 .60 & 5 th week & $3 \cdot 09$ & Unilateral cataract & + & + & + & Probable \\
\hline 11 & 29.11.61 & 3 weeks & $2 \cdot 95$ & $\begin{array}{l}\text { Mild chorioretino- } \\
\text { pathy }\end{array}$ & + & & & Probable \\
\hline 12 & 27.2 .63 & 4 weeks & $2 \cdot 13$ & $\begin{array}{l}\text { Unilateral cataract; } \\
\text { chorioretinopathy }\end{array}$ & - & - & + & Probable \\
\hline 13 & 18.4 .63 & 2nd week & $3 \cdot 23$ & Bilateral cataract & + & - & + & Probable \\
\hline 14 & 8.10 .63 & 3 weeks & $2 \cdot 47$ & Bilateral cataract & $?$ & $?$ & + & Probable \\
\hline
\end{tabular}

* European migrant family.

$\dagger$ Died aged $3 \frac{1}{2}$ months.

$\ddagger$ Foster child.

TABLE II

Proven Cardiovascular Anomalies

\begin{tabular}{c|c|c|c|c|c}
\hline Case No. & $\begin{array}{c}\text { Patent ductus } \\
\text { arteriosus }\end{array}$ & $\begin{array}{c}\text { Pulmonary } \\
\text { valve }\end{array}$ & $\begin{array}{c}\text { Main } \\
\text { pulmonary } \\
\text { arteries }\end{array}$ & $\begin{array}{c}\text { Pulmonary artery } \\
\text { branches }\end{array}$ & Other anomalies \\
\hline 1 & - & Stenosis & Small & $\begin{array}{c}\text { Bilateral stenosis at } \\
\text { bifurcation } \\
\text { Bilateral stenosis at } \\
\text { bifurcation } \\
\text { Bilateral stenosis at } \\
\text { bifurcation } \\
\text { Bilateral narrowing of } \\
\text { main branches } \\
\text { Bilateral stenosis at } \\
\text { bifurcation }\end{array}$ & $\begin{array}{c}\text { Intimal thickening of } \\
\text { aorta and coronary } \\
\text { arteries } \\
\text { Atrial septal defect }\end{array}$ \\
\hline 5 & $\begin{array}{c}\text { Small } \\
\text { (ligated) }\end{array}$ & Stenosis & $\begin{array}{c}\text { Variable } \\
\text { size } \\
\text { Normal }\end{array}$ & - & Normal \\
\hline
\end{tabular}

* Small in diastole, dilating in systole.

$\uparrow$ Necropsy findings.

TABLE III

Catheterization Findings

\begin{tabular}{|c|c|c|c|c|c|c|c|c|c|c|c|}
\hline & & \multicolumn{4}{|c|}{ Pressures (mm. Hg) } & \multicolumn{6}{|c|}{ Oxygen saturations $(\%)$} \\
\hline & & R.V. & M.P.A. & R.P.A. & L.P.A. & S.V.C. & R.A. & R.V. & M.P.A. & R.P.A. & L.P. \\
\hline $\begin{array}{l}\text { Case 1. (J.W.) } \\
\text { Case 2. (M.L.) } \\
\text { Case 3. (B.S.) } \\
\text { Case 5. (L.A.) }\end{array}$ & $\begin{array}{l}\cdots \\
\cdots \\
\cdots \\
\cdots\end{array}$ & $\begin{array}{c}120 / 0 \\
90 / 0 \\
110 /-3 \\
57 / 12^{*}\end{array}$ & $\begin{array}{l}50 / 10 \\
48 / 8 \\
60 / 40^{*}\end{array}$ & $\begin{array}{l}\text { ot entered } \\
\frac{12 / 5}{20 / 15^{*}}\end{array}$ & $\begin{array}{c}15 / 5 \\
15 / 8 \\
-\end{array}$ & $\begin{array}{l}72 \\
74 \\
53\end{array}$ & $\begin{array}{l}72 \\
74 \\
59 \\
71\end{array}$ & $\begin{array}{l}68 \\
76 \\
63 \\
72\end{array}$ & $\begin{array}{l}\overline{92} \\
63 \\
85\end{array}$ & $\frac{\overline{87}}{78}$ & $\overline{59}$ \\
\hline
\end{tabular}

* Somewhat damped tracings taken through No. 5 Lehman catheter. 


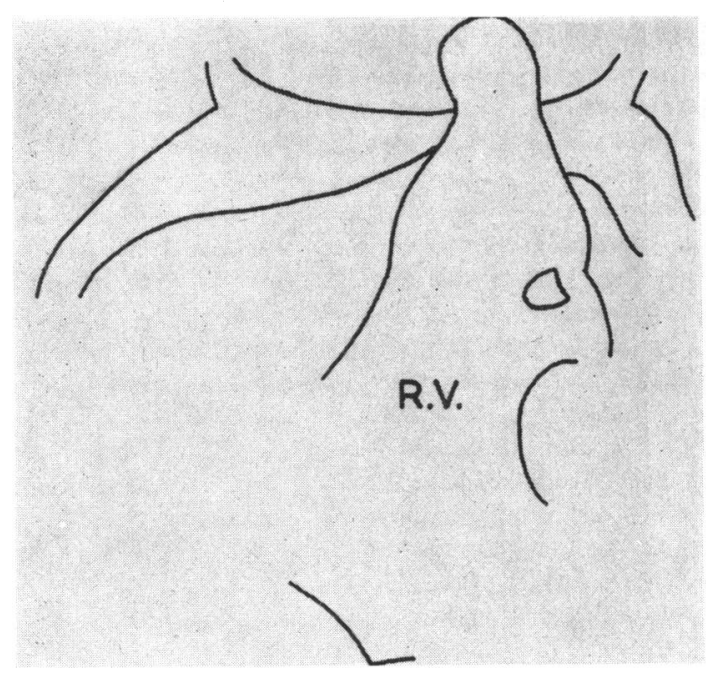

A

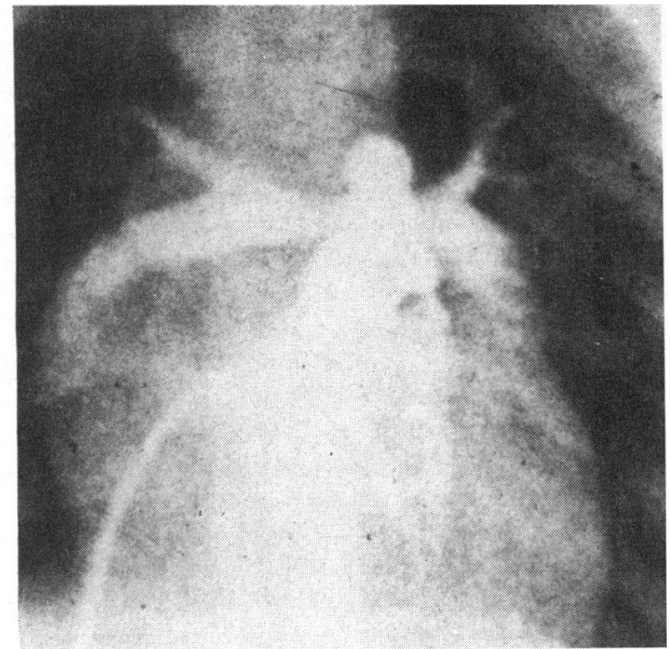

B

FIG. 1.-Antero-posterior view of selective right ventricular angiogram (Case 1). Reproduction of single frame of $35 \mathrm{~mm}$. cine recording. Narrowing of origin of right pulmonary artery with poststenotic dilatation of right and left pulmonary artery branches.

Table II summarizes the cardiovascular abnormalities present in the fully documented cases (Cases 1 to 5), while Table III demonstrates the catheterization findings. In each case investigated, selective angiocardiography demonstrated bilateral narrowing of the main pulmonary artery branches at least at their origin from the main pulmonary artery (Fig. 1, 2, and 4). In Case 4, who died at the age of $3 \frac{1}{2}$ months weighing $3.5 \mathrm{~kg}$., necropsy revealed tubular narrowing of both main right and left pulmonary artery branches. The internal diameter of the main pulmonary artery was $8.0 \mathrm{~mm}$., while the internal diameter of each of the main branches was $2.5 \mathrm{~mm}$. This infant is of further interest because of diffuse intimal thickening affecting the aorta and coronary arteries in addition to the pulmonary arterial tree (Campbell, 1965). In three cases pulmonary valve stenosis

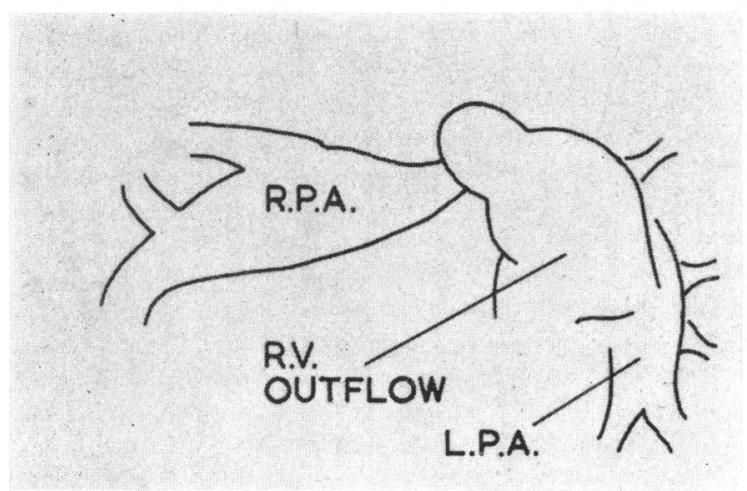

A

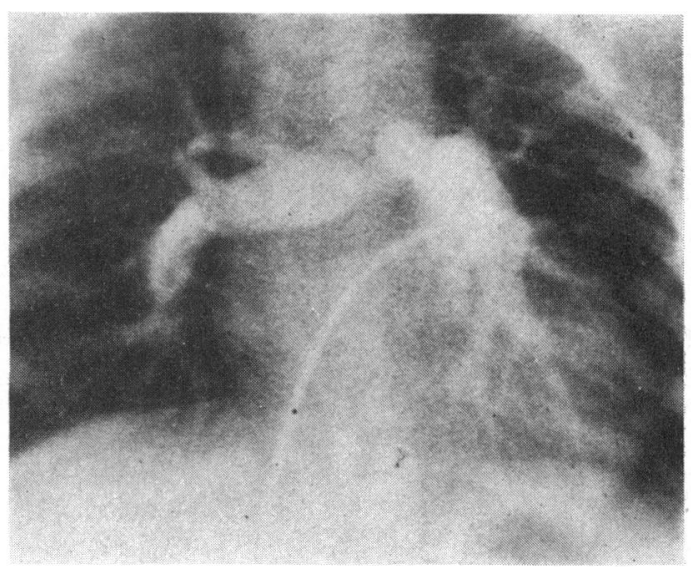

B

FIG. 2.-Antero-posterior view of selective right ventricular angiogram (Case 2). Reproduction of single frame of $35 \mathrm{~mm}$. cine recording. Small main pulmonary artery, narrowing of origin of right pulmonary artery, and post-stenotic dilatation of right pulmonary artery. 


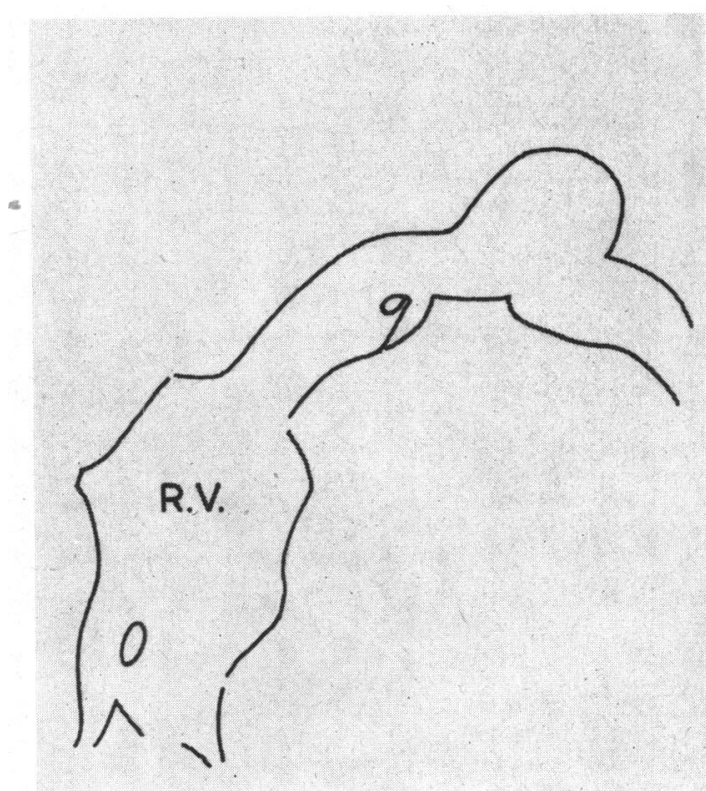

A

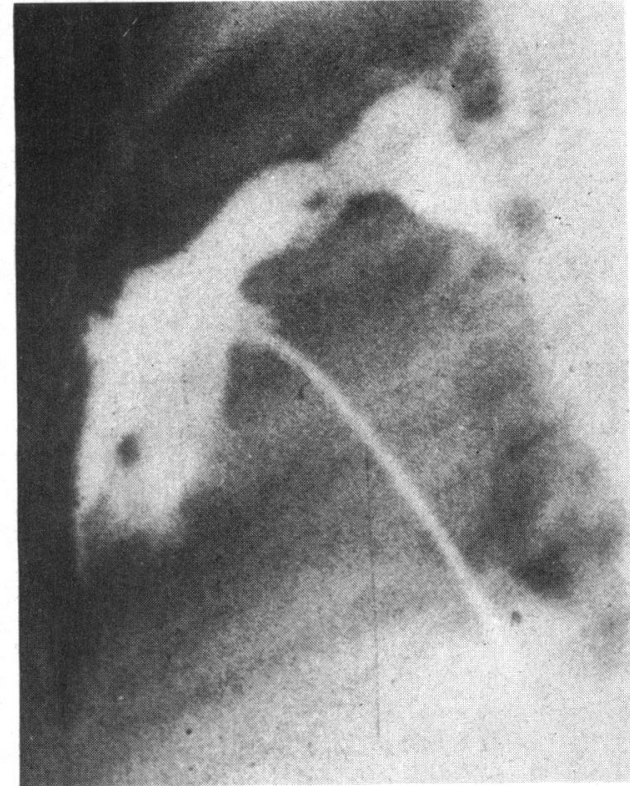

B

FIG. 3.-Lateral view of selective right ventricular angiogram (Case 1). Reproduction of single frame of $35 \mathrm{~mm}$. cine recording.

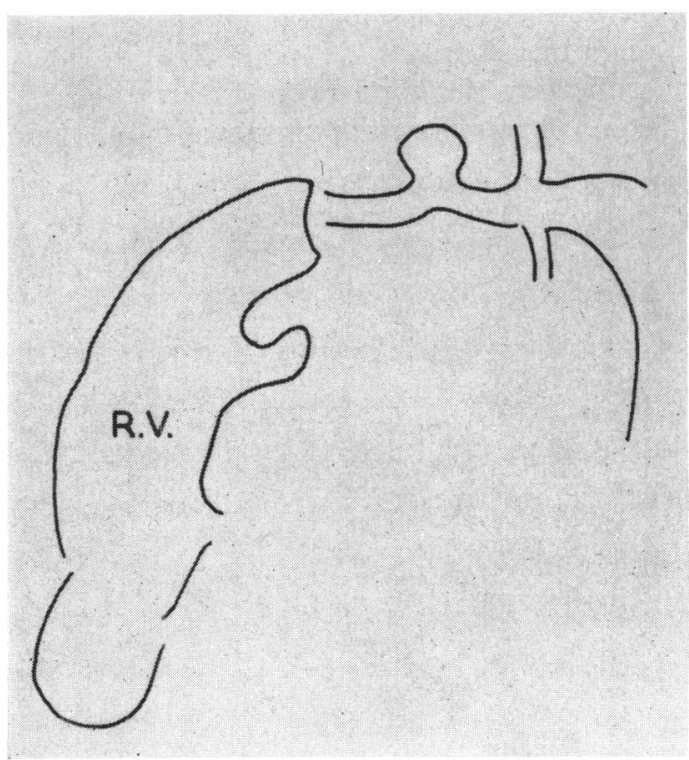

A

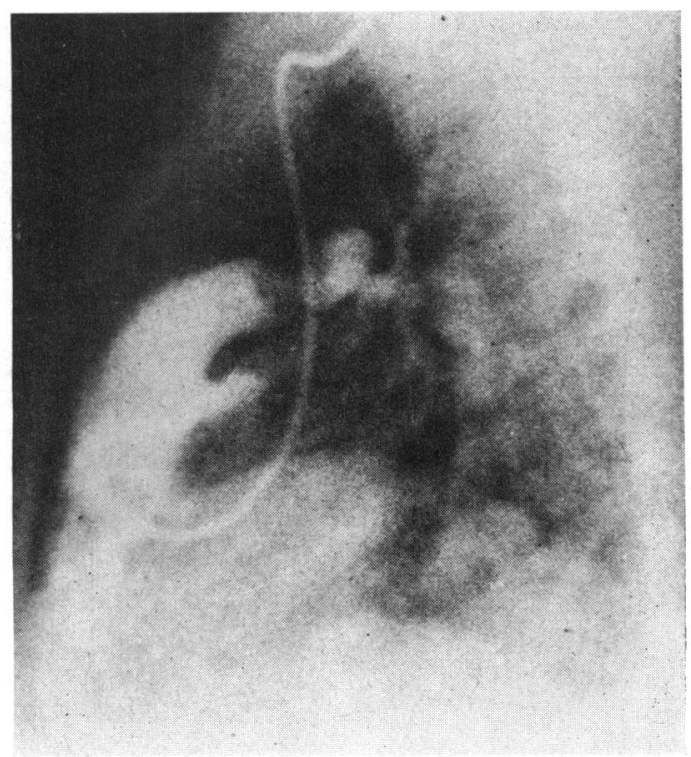

B

FIG. 4.-Lateral view of selective right ventricular angiogram (Case 3). Reproduction of single frame of $35 \mathrm{~mm}$. cine recording. Film in diastole early in run. Shows unusual appearance of main pulmonary artery and stenosis of origin of left pulmonary artery. 


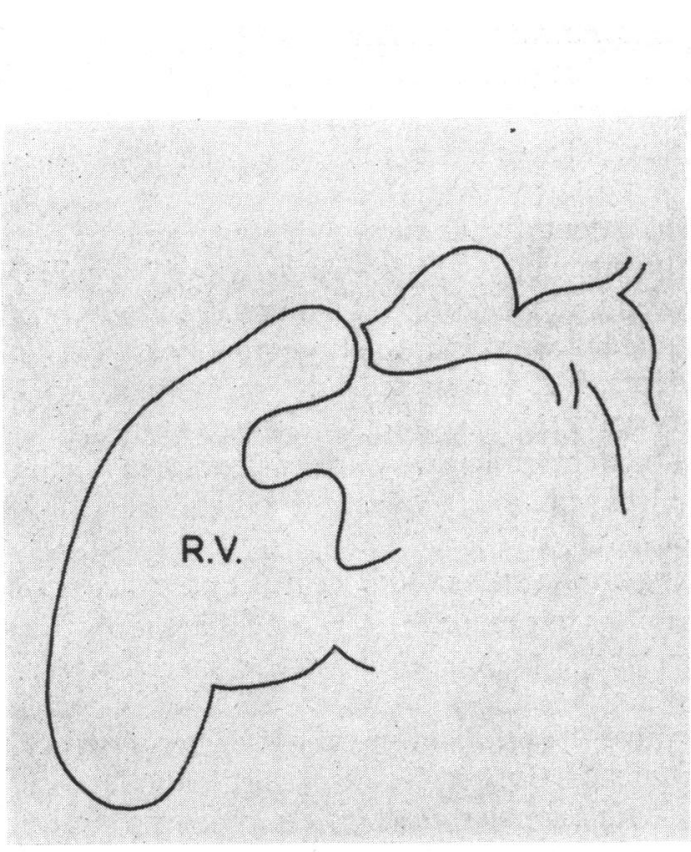

A

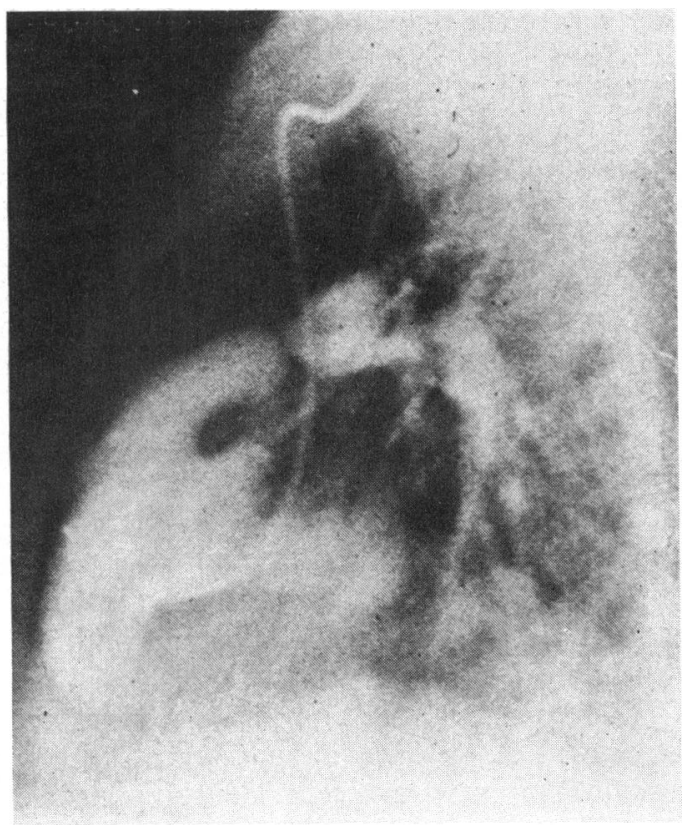

B

FIG. 5.-Lateral view of selective right ventricular angiogram (Case 3). Film in systole later in run than Fig. 4 shows dilatation of main pulmonary artery. Pulmonary. valve stenosis demonstrated. Some tricuspid reflux.

was evident either from pressure recordings or from the lateral angiograms (Fig. 3). The main pulmonary artery appeared to have an unusual configuration, presumably due to the stenosis. In Cases 1 and 2, its size was fairly constant throughout the cardiac cycle. In Case 3 it was small in diastole but dilated quite considerably during ventricular systole (Fig. 4, 5).

Of the 9 patients in whom the anatomy of the right ventricular outflow tract and pulmonary arteries has not been fully worked out, 3 have in fact been catheterized. Two infants with large left-to-right shunt through a patent ductus had right ventricular and main pulmonary artery hypertension. Pulmonary stenosis was not suspected at the time, but both have suggestive residual systolic murmurs following closure of the ductus. Review of the selective angiogram performed in one of these infants suggests the possibility of narrowing of at least the left pulmonary artery at its origin from the main pulmonary artery, but further investigation would be needed to elucidate the situation. In the third child cardiac catheterization at another hospital demonstrated a gradient across the right ventricular outflow tract interpreted as being due to pulmonary valve stenosis, but angiocardiography was not performed.

\section{COMMENT}

The patients whose details are summarized in Table I have been selected because of the presence of signs of pulmonary stenosis, and therefore all have cardiovascular involvement. Their other features are in accord with the recognized effects of rubella at this stage of pregnancy (Blattner, 1959; Skinner, 1961; Pitt, 1961). In Case 2 and in Case 7 there is no clear history of rubella in pregnancy. The relevant information is not available for Case 6, who is a foster child. These patients have been included in the group because of their over-all picture, in which deafness or cataract is associated with patent ductus and evidence of pulmonary stenosis. The accuracy of diagnosis of rubella in the other cases is subject to the usual criticisms of retrospective information in this field. 
It is not clear what part prematurity plays in the low birth weights frequently observed. Case 5, for instance, was born one week before the estimated due date of delivery but appeared obviously premature. Further inquiry revealed that her mother had not come into labour in her previous pregnancies for two to three weeks after the due date. There has been a general tendency for subsequent growth retardation in these children.

Stuckey (1956) and Campbell (1961) emphasized patent ductus among the types of cardiac anomaly resulting from maternal rubella during early pregnancy. Pulmonary stenosis occurring in association with patent ductus was discussed by Heiner and Nadas (1958) with relation to its possible origin in maternal rubella. Rowe (1963) demonstrated the importance of pulmonary artery stenosis following maternal rubella. He described 11 patients, 9 of whom had bilateral pulmonary artery stenosis: 10 of the 11 had some degree of pulmonary valve stenosis, and 3 had a patent ductus. The 5 documented patients of the present series all had bilateral pulmonary artery stenosis involving the area of bifurcation of the main pulmonary artery; 3 had pulmonary valve stenosis and 4 had a patent ductus. No peripheral pulmonary arterial stenoses were defined. Pulmonary valve stenosis was stated to be present in the three cases of pulmonary arterial stenosis described by Arvidsson et al. (1961) and referred to by Rowe (1963), although the pressures recorded suggested that the obstruction was mild. Two of these patients had multiple peripheral pulmonary arterial stenoses, and one a central lesion.

The frequent association between pulmonary valve stenosis and pulmonary arterial stenosis of both central and peripheral types indicates the widespread nature of the effects of the rubella virus on the pulmonary arterial tree. The component of arterial stenosis deserves the emphasis given it by Rowe (1963), since it explains important clinical signs which in turn aid diagnosis. The over-all picture that emerges in this syndrome of pulmonary stenosis following maternal rubella, however, remains one of often complex diffuse narrowing which must be elucidated fully because of its surgical implications. The degree of narrowing of the pulmonary valve ring, the size of the main pulmonary artery, and the arterial stenosis must all be considered carefully in making any decision regarding surgical management. In Case 1 of the present report, previous catheterization at another hospital had appeared on the pullback tracing to show simple pulmonary valve stenosis, a finding that confirms the need for selective angiocardiography in all patients with the syndrome whose right ventricular loading justifies investigation. The common association of the syndrome with patent ductus must also be emphasized.

In the 9 patients of the present series who have not been fully documented, the degree of right ventricular loading has not so far been considered sufficient to warrant further study. It is most important that the possible nature of their lesion be appreciated, and that they should continue to be observed, since, as Rowe (1963) points out, the ultimate prognosis is unknown. It is similarly important that all patients with patent ductus secondary to maternal rubella be scrutinized carefully not only for deafness, but also for this additional cardiovascular lesion.

\section{SUMMARY}

Of a total group of 14 children, 5 patients with the syndrome of pulmonary stenosis following maternal rubella during pregnancy have been documented fully by investigation or by necropsy. All 5 patients showed bilateral pulmonary artery stenosis as part of their cardiovascular anomaly. The cardiovascular findings are described together with the general findings in the whole group. These findings demonstrate the common association of this syndrome of pulmonary stenosis with patent ductus, and emphasize the complexity of the obstruction to pulmonary flow present in such patients.

\section{REFERENCES}

Arvidsson, H., Carlsson, E., Hartmann, A., Tsifutis, A., and Crawford, C. (1961). Supravalvular stenoses of the pulmonary arteries. Report of eleven cases. Acta radiol. (Stockh.), 56, 466.

Blattner, R. J. (1959). Rubella during pregnancy (current comment). J. Pediat., 54, 257. 
Campbell, M. (1961). The place of maternal rubella in the ætiology of congenital heart disease. Brit. med. J., 1, 691.

Campbell, P. E. (1965). Vascular abnormalities following maternal rubella. Brit. Heart J., $27,134$.

Heiner, D. C., and Nadas, A. S. (1958). Patent ductus arteriosus in association with pulmonic stenosis. Circulation, 17, 232.

Pitt, D. B. (1961). Congenital malformations and maternal rubella: progress report. Med.J. Aust., $1,881$.

Rowe, R. D. (1963). Maternal rubella and pulmonary artery stenoses. Report of eleven cases. Pediatrics, 32, 180.

Skinner, C. W. (1961). The rubella problem. Amer. J. Dis. Child., 101, 78.

Stuckey, D. (1956). Congenital heart defects following maternal rubella during pregnancy. Brit. Heart J., 18 519. 